\title{
AL-QUR'AN DALAM SEJARAH PENAFSIRAN INDONESIA: ANALISIS-DESKRIPTIF BEBERAPA TAFSIR DI INDONESIA
}

\author{
Siti Fahimah \\ IAI Tarbiyatut Tholabah Lamongan \\ Email: fahimahsiti@gmail.com
}

\begin{abstract}
Abstrak: Sejarah penafsiran di Indonesia tidak kalah penting dan maraknya dengan sejarah penafsiran dalam dunia Arab. Penafsiran di Indonesia dimulai sejak awal abad ke-17 hingga sekarang dengan berbagai genre. Maraknya penafsiran yang dihasilkan orang Indonesia menandakan bahwa al-Quran ingin difahami dalam konteks keindonesiaan dengan bahasa dan pendekatan yang beragam sebagaimana back ground penulis. Adapun jumlah dan pengkatagoriannya sangat banyak, ada yang menggunakan metode dan pendekatan tematik ada juga yang memahami secara keseluruhan al-Quran dengan mengadopsi cara dan metode mufassir klasik Arab. Dalam tulisan ini penulis berhasil menemukan dan mendeskripsikan beberapa kitab yang terkategorikan sebagai tafsir dan dihasilkan orang Indonesia, tidak menutup kemungkinan masih banyak tafsir di Indonesia yang belum terjamah, bahkan masih akan muncul lagi karya-karya anak bangsa dalam merespon keberagamaan di Indonesia yang dimunculkan dalam bentuk tafsir. Adapun pengulasan tafsir yang dituangkan dalam tulisan ini hanya sekadar mendeskripsikan saja, sekitar sosok penulis tafsir secara umum kemudian model dan corak nya.

Kata Kunci: Tafsir Indonesia, sejarah, al-Quran
\end{abstract}

Abstract: The history of interpretation in Indonesia is no less important and rampant with a history of interpretation in the Arab world. Interpretation in Indonesia began in the early 17 th century up to now with various genres, the rise of interpretations produced by Indonesians indicates that the Koran wants to be understood in the context of Indonesia with a variety of languages and approaches as well as the writer's back. The number and categorization are very many, some use thematic methods and approaches there are also those who understand the Qur'an as a whole the Koran by adopting the classical Arabic exegetical methods and methods. In this paper the author has succeeded in discovering and describing 22 books categorized as interpretations produced by Indonesians in various patterns and methods, not to the possibility that there are still many interpretations in Indonesia that have not yet been touched. Indonesia is presented in the form of interpretation. As for the interpretation of interpretations as outlined in this paper just to describe it, around the figure of the interpreter in general, then the model and style.

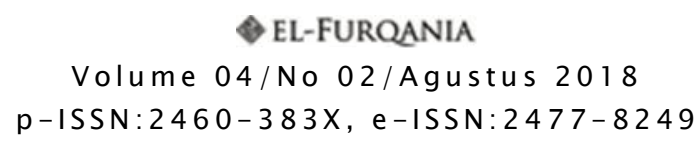


Keywords: Indonesian interpretation, history, al-Quran

\section{Prolog}

Secara garis besar; sejarah aktifitas penafsiran al-Quran di Indonesia dibagi menjadi tiga periode besar: klasik, modern dan kontemporer. Periode klasik dimulai sejak awal abad ke-17 hingga akhir abad ke-19, hal ini terbukti dengan ditemukanya manuskrip tafsir atas Surat al-Kahfi berbahasa Melayu yang diperkirakan disusun sekitar tahun $1600 \mathrm{M}$ kemudian disusul dengan dikarangnya Tarjuman al-Mustafid oleh Abd Rauf Sinkel yang dianggap sebagai penafsiran yang gamblang dan jelas.

Periode kedua membentang dari paruh pertama abad ke-20 sampai dengan awal tahun 1980-an, pada periode ini-pun dibagi menjadi dua masa yaitu masa pra-kemerdekaan dan masa pasca kemerdekaan yang meliputi jangka waktu permulaan abad ke-20 sampai tahun 1945, dan yang membentang dari tahun 1945 sampai sekarang, tetapi oleh sebagian pengkaji dikategorikan bahwa dari tahun 1980-an sampai sekarang periode kontemporer.

Berdasarkan klasifikasi tersebut akan dianalisis masing-masing karya yang berhasil dihasilkan oleh ilmuwan Nusantara khusunya dalam bidang tafsir, karena berdasarkan data yang didapatkan ternyata penafsiran di Indonesia telah berkembang sejak lama, bahkan orang Indonesia sendiri tidak banyak mengetahui karya-karya yang dihasilkan orang Indonesia. Oleh karena itu -paling tidak- tafsir yang telah didapatkan akan penulis analisa metode dan cara mereka menafsirkan sekaligus sebagai langkah awal untuk memperkenalkan karya anak bangsa.

Selain itu juga, ternyata peralihan periode menimbulkan peralihan model, cara, corak dan tujuan karena ternyata orientasi aktivitas penafsiran yang ada tidak lagi hanya menciptakan tafsir tetapi juga memikirkan bagaimana menciptakan tafsir dengan pertanyaan mendasarkan "bagaimana memahami, menafsirkan dan mendekati al-Quran sesuai dengan konteks kekinian dan kedisinian" Kedisinian yaitu pada masa sekarang ini dan dalam konteks situasi dan kondisi Indonesia sekarang ini. Pertanyaan semacam ini dijawab oleh para cendekiawan Muslim dengan mencurahkan berbagai usaha untuk menemukan suatu metode dan pendekatan penafsiran al-Quran. Tafsir yang akan dideskripsikan dengan sedikit analisis metode dan corak adalah yang dihasilkan oleh orang Indonesia asli dengan model penafsiran secara keseluruhan al-Qur'an. ${ }^{1}$

\footnotetext{
${ }^{1}$ Tafsir-tafsir yang ada hanya sebagian dengan tidak berpatokan pada kriteria tertentu, tetapi data yang didapatkan adalah berdasarkan referensi yang ada. Nashrudin Baidan, Perkembangan Tafsir al-Quran di Indonesia, (Tiga Serangkai, 2003)
} 


\section{Marah Labid Karya Nawawi al-Bantani ${ }^{2}$}

Nama lengkap tafsir ini adalah al-Tafsir al-Munir li Ma'ālim alTanzīl al-Musfiru 'an wujūhi mahāsin al-Ta'wìil yang dikenal tafsir Marah Labid yang dikarang oleh anak bangsa yaitu Muhammad bin Umar bin

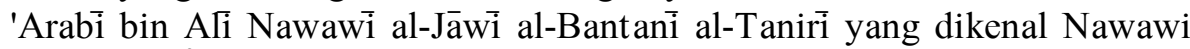
al-Bantani. ${ }^{3}$ Walaupun karya ini adalah merupakan karya orang Nusantara tetapi tafsir ini ditulis dalam bahasa Arab berbentuk dua jilid besar. Secara terperinci tidak jelas mulai kapan karya ini ditulis, tetapi tafsir ini telah dicetak tahun 1887 yang bertujuan untuk melestarikan pemikiran atau hasilhasil karya ulama klasik semisal Ibnu Kathīr, Jalāl al-Dīn al-Mahalli dan Jalāl al-Dīn al-Suyūtị, maka tidak heran jika metode yang dipakai adalah seperti halnya ulama yang telah mempengaruhinya.

Seperti halnya suatu karya maka yang dihasilkan tidak akan terlepas dari motifasi awal dalam menulis. Begitu juga dengan halnya Marah labid, Dalam menulis karyanya seperti yang diungkapkan dalam muqaddimah tafsirnya beliau termasuk ulama yang cenderung tradionalis dengan hanya melihat karangan-karangan ulama klasik, sehingga Upayanya ini terekam dalam bentuk (manh $\bar{j}$ ) tafsirnya yang cenderung ma'th $\bar{u}$, terbukti ketika Nawawi menjelaskan ayat maka dia akan merujuk pada pengertian yang terdapat dalam ayat yang lain ataupun hadis untuk menjelaskan akan pengertian ayat yang sedang dibahas.

Mengenai corak yang dipakai oleh Nawawi, ada beberapa corak yang dia pakai yaitu sufi dan bahasa. Hal itu didasarkan dari pendekatan dia dalam menafsirkan terkadang cenderung sufistik, hal itu dimungkinkan dari keterpengaruhan dia dengan karya Ibn 'Arabī khususnya Futūhät alMakkiyah bahkan ada asumsi bahwa karya Nawawi ini terpengaruh dari Futūhăt al-Makkiyah, terkadang lughawī at au zăhirī karena diduga kuat dia dalam menafsirkan ayat sangat terpengaruh dengan tafsir al-Jalālain yang memang penafsiranya cenderung lughawi. ${ }^{4}$

Di sisi lain karena tafsir ini banyak yang memaparkan hal yang dianggap sebagai tolak ukur penafsiran yang baik, maka tafsir ini juga mempunyai banyak keistemewaan, diantaranya menyebutkan makna-makna surat serta nama-namanya dan diteruskan dengan menjelaskan kandunganya dalam berbagai aspek, di lain hal, Nawawi juga menjelaskan aspek qirāàt jika memang didapatkan perbedaan qiräăt oleh imam qurrä', tetapi ironisnya, hal itu hanya berupa pemaparan secara umum tanpa adanya

\footnotetext{
${ }^{2}$ Muhammad al-Jawi Nawawi, Marah Labid Tafsir al-Nawawi, Vol.I ( Surabaya: alhidayah, t.t), 10

${ }^{3}$ Samsul Munir Amin, Sayyid Ulama Hijaz: Biografi Syaikh Nawawi al-Bantani, (Jakarta, Bulan Bintang, t.t), 21.

${ }^{4}$ Islah Gusmian, Khazanah Tafsir di Indonesia, (Jakarta: Teraju, 2002), 34
} 
penyaringan qirāàt yang șahìh dan tidak, sehingga sangat dimungkinkan adanya unsur israiliyāt yang masuk.

\section{Tafsir Al-Qur'an Al-Karim Karya Mahmud Yunus}

Karya ini ditulis oleh orang yang sangat produktif dan "penting" dalam high politik Indonesia pada saat itu yaitu Mahmud Yunus kelahiran Sumatera Barat tahun 1899. ${ }^{5}$ Walaupun pada saat dia hidup pembaharuan belum begitu membumi dan masih merupakan hal yang sangat "baru" bagi orang awam, tetapi dia telah menerimanya bahkan sangat berpengaruh dalam dirinya. Hal itu dia dapatkan dari pendidikan dia yang bersifat modernis sehingga tidak heran jika faham mu'tazilah pun -yang cenderung modernis- mempengaruhinya. Secara praktis, Hal itu tampak dalam karya dia yaitu tafsir al-Quran al-Karim dengan menerjemahkan al-Quran dalam bahasa Indonesia, padahal pada masanya hal itu sangat ditentang dan bahkan mendapatkan label haram oleh ulama-ulama saat itu. ${ }^{6}$

Tafsir ini ditulis dalam kurun waktu yang cukup lama dalam masa pra-kemerdekaan, sehingga sangat wajar kalau motivasi awal dari penulisan karya ini adalah untuk memerdekakan bangsa dari ketertindasan kolonial Belanda dan penjajah yang menjajah Indonesia pada saat itu. Di sisi lain, penulisan tafsir ini tidak langsung dalam satu waktu secara kontinu, karena pada tahun 1923 baru selesai tiga juz dan berhenti cukup lama baru sepuluh tahun kemudian dilanjutkan lagi meneruskan penafsiran yang sempat tertunda yaitu tahun 1935 dengan menerjang komentar dan kritikan yang ditujukan kepadanya, kerena adanya pelarangan al-Qur'an untuk diterjemahkan tetapi berkat keberanian dia untuk memulai sesuatu yang "baru". Selain itu juga karena adanya dukungan ulama kairo yaitu Syaikh Dar Ulum tempat dia belajar yang mengatakan bahwa menerjemahkan alQur'an adalah mubah bahkan sampai pada hukum farḍ kifäyah, maka banyak pula muncul karya yang mengikuti jejak dia, karena tafsir ini dikatakan tafsir pertama pada periode kedua dalam bentuk terjamah, seperti halnya al-Furqan karya Ahmad Hasan dan tafsir al-Quran karya al-Hamidi. Tafsir ini dikategorikan yang muncul pada periode kedua. ${ }^{7}$

Seperti halnya penafsiran yang muncul periode kedua, tafsir alQur'an alkarim ini-pun sama dalam cara menyusunya, tetapi yang dimiliki tafsir ini lain dari penafsiran lain dan dianggap sebagai keistemewaan-nya yaitu dengan mengakhiri dengan kesimpulan isi al-Quran sebanyak 32

\footnotetext{
${ }^{5}$ Herry Muhammad, dkk. Tokoh-tokoh Islam yang Berpengaruh Abad 20, (Depok: Gema Insani, 2006), 34

${ }^{6}$ Amursid M dan Amarudin Asra, Studi Tafsir Quran Karim karya Mahmud Yunus, Jurnal Syahadah, Vol 3, No.2, Oktober 2015, 55

${ }^{7}$ Mahmud Yunus, Tafsir al-Quranil Karim, (Jakarta: PT. Mahmud Yunus wa Dzurriyah, 2015), 67
} 
halaman, sekitar ada 24 hal yang dia kemukakan didalamnya, tetapi yang terpenting adalah mengenai hukum taklifi yang lima yaitu wajib, haram, sunat, makruh, $d$ an mubah, rukun iman, rukun Islam dan berbagai masalah kehidupan seperti ekonomi, kesehatan, pemerintahan, sejarah, waris. Semua itu tidak lepaskan begitu saja tetapi juga menyertakan ayat-ayat al-Quran yang yang berhubungan dengan masalah-masalah tersebut. Selain itu untuk mendapatkan tujuan yang ingin dicapai, Mahmud Yunus menjelaskan dan menerangkan petunjuk yang termaktub al-Quran untuk diamalkan.

Dalam penulisan tafsirnya, Mahmud Yunus menggunakan metode tahlifi yaitu sesuai dengan urutan yang ada dalam al-Quran, yaitu dari surat al-fatihah sampai al-Nās dengan bersumberkan dari al-Quran itu sendiri, hadis-hadis shahih, perkataan sahabat untuk mengambil sumber yang ada hubunganya dengan asbāb al-nuzūl, perkataan tabi'in, bahasa Arab yang umum digunakan, ijtihăd para mujtahid, selain itu juga, ia sering menggunakan nalar sesuai dengan konteks perkembangan pemikiran dia, tetapi lain halnya dengan penafsiran yang bersifat cerita, dia menafsirkan banyak yang leterlek sesuai dengan teks al-Quran, karena dia tidak mahu bahkan sangat melarang mengambil dari cerita-cerita israiliyāt yang berkenaan dengan penafsiran yang qașaș. Hal itu dikhawatirkan masuknya pengaruh israiliyāt dalam suatu penafsiran, karena cerita-cerita kenabian itu rentan dimasuki israiliyăt.

Selain itu, penafsiran Mahmud Yunus juga banyak dipengaruhi oleh para pemikir yang cenderung rasioanalis dan merupakan interpretasi dari penafsir modernis, seperti halnya Abduh dalam karyanya al-Manār. Hal itu bisa dilihat dari cara Mahmud Yunus menafsirkan surat al-Nisā' ayat 126. tidak hanya pemikiran Abduh yang mempunyai andil dalam membentuk pemikiran Mahmud Yunus, Ibnu 'Arabì-pun turut andil dan juga pemikiran paham Mu'tazilah.

Persentuhan dia dengan aspek dan kondisi yang modern bisa dilihat ketika dia menafsirkan surat al-Baqarah khusunya ayat 1-5, dalam menafsirkan salah satu ayat ke-3 Mahmud Yunus menyertakan fenomena yang berkembang pada saat itu, Didalamnya dia juga menyinggung tentang kondisi orang-orang serta realitas yang ada pada abad XX, didalamnya dia mengatakan bahwa "pada abad XX ini sudah banyak professor di Eropa dan Amerika yang telah percaya pada yang ghaib, yaitu tatkala mereka menyelidiki ikmu spiritual dan ilmu hypnotisme (mesmerisme) dengan percobaan mereka telah banyak orang-orang terpelajar di Eropa yang percaya akan adanya roh manusia, sebagai pokok bagi mereka untuk percaya kepada Allah, malaikat dan sebagainya" Selain ini masih banyak penafsiran dia yng modernis dan sesuai dengan realiras yang ada. Sementara ayat yang lain ditafsirkan dengan apa yang ada dalam teks.

Dengan memperhatikan model Mahmud Yunus di atas, bisa dikatakan bahwa tafsir al-Quran al-Karim ini memakai metode tahlili yang 
bercorak adabi ijtimāí, hal itu banyaknya dia menafsirkan dengan melihat kondisi yang berkembang di masyarakat dengan memberikan al-Quran sebagai suatu solusi.

\section{Tafsir al-Ibriz Karya KH Bishri Musthafa}

Salah satu karya lain yang fenomenal dan mempunyai keunikan tersendiri adalah karya KH Bishri Mushtafa yang disusun dengan bahasa Jawa yang sarat dengan aturan dan unggah-ungguh orang jawa, karena memang diJawa sendiri ada kekhasan dan bisa disebut semacam hirarki berbahasa yang tingkat kehalusan dan kekasaran diksinya sangat tergantung pihak-pihak yang berdialog. Tafsir ini disusun oleh KH Bishri Mushtafa seorang ulama yang kharismatik, cerdas, produktif dan juga politikus dengan banyak talenta yang dipunyainya, terbukti selain sebagai seorang santri, kiyai dia juga seorang praktisi politik sehingga wajar jika dia dijuluki sebagai tokoh tiga zaman (zaman penjajah, zaman pemerintahan soekarno, dan pemerintahan Soeharto) dengan memberikan nama tafsirnya al-Ibriz li Ma'rifah Tafsir al-Qur'ān al-Aziz yang memuat ayat secara lengkap 30 juz mulai dari surat al-Fātihah sampai surat al-Nās, tetapi kemudian tafsir ini lebih dikenal dengan tafsir al-Ibriz.

Asumsi awal yang muncul ketika melihat tafsir ini adalah bahwa penulis ingin mempersembahkan karyanya kepada orang-orang yang ada dikalanganya yaitu Jawa yang hanya bertaraf lokal, hal itu terbukti dengan ditulisnya tafsir ini dengan bahasa Jawa yang sulit bahkan tidak mungkin difahami oleh orang selain Jawa, hal itu diasumsikan kentalnya KH. Bishri dengan adat jawa dan juga pendidikan dan lingkungan yang ada dan membentuk perkembangan pemikiran dia. $^{8}$

Terlepas dari itu semua, tidak menghilangkan signifikansi dan nilai tafsir itu sendiri, toh ternyata tafsir ini menurut penulisnya juga mengambil sumber penafsiranya kepada kitab-kitab klasik yang masih dianggap mu'tabar seperti tafsìr al-Jalālain, Tafsìr al-Baiḍ̂â̄i, Tafsìr al-Khāzin dan lain-lain dan juga secara otomatis dimasukkan ide-ide dan pemikiranya. Tetapi sayangnya KH. Bishri seolah-olah menulis tafsir ini murni dari pikiran dia, karena tidak secara langsung dan jelas menyebutkan dari mana dia menukil pendapatnya dan membiarkan tafsiran itu "lepas".

Dalam hal sistematika atau model dalam menulis, KH. Bishri memakai cara menulis al-Quran di tengah dengan diberi makna gandul seperti halnya tradisi yang berkembang di pesantren Jawa khususnya Jawa Timur, sedangkan penafsiran ditulis dibagian pinggir dan kalu ada yang memang perlu ditambhakan berkenaan dengan penafsiran ayat itu KH. Bishri menulisnya dalam kategori tanbīh, fäidah, muhimmah. Tetapi

\footnotetext{
${ }^{8}$ Abu Rokhmad, Telaah Karakteristik Tafsir Arab-Pegon al-Ibriz, Jurnal 'Analisa' Vol. XVIII, No. 01, Januari-Juni 2001, 32
} 
kategori inipun tidak jelas bahkan menimbulkan kerancuan dan tumpang tindih, artinya tidak ditemukan mana yang masuk tanbỉh, mana yang fäidah dan mana yang muhimmah, kadang asbāb al-nuzūlmasuk di kategori tanbīh dan kadang pula masuk dalam muhimmah dan kasus serupa yang lain. ${ }^{9}$

Adapun metode yang digunakan KH. Bishri dalam menyusun tafsirnya berdasarkan penerapan tafsirnya dapat dikatakan sebagai metode tahlifi karena menafsirkan ayat demi ayat berdasarkan runtutan ayat yang ada dalam al-Quran seperti halnya Tafsìr al-Jalālain yang cenderung global, ringkas dan jelas. Hal itu dimungkinkan dari tujuan dia semula menulis yaitu agar masyarakat khusunya orang Jawa yang ada disekitarnya mampu memahami kandungan al-Quran dengan seksama, baik kaum inteklektual, kalangan pesantren bahkan orang awam sekalipun. Sedangkan Manhäjyang dia pakai adalah al-Ma'thür, terbukti di dalam tafsirnya terkadang dia menampilkan hadis-hadis Nabi untuk memperkuat penafsiran atau untuk menafsirkan ayat, tetapi sayangnya hadis yang dia cantumkan dia lepaskan begitu saja tanpa adanya penyaringan, bahkan sanad-pun tidak dicantumkan sehingga kulaitas hadis itu tidak dikatahui sahīh, hasan atau ḍaif-nya. Selain menampilkan hadis, kiai Bishri juga menukil pendapat para sahabat, seperti dalam kasus ayat satu surat al-Baqarah, alif läm Mim dia menggunakan penafsiran Ibnu Abbās, kemudian dalam surat al-Isrā' ayat 111 dia juga menukil pendapat Aishah r.a dan Ibn Abbās. Tetapi sayangnya, kiai Bishri tidak memberikan informasi dan memberikan penjelasan dari mana dia menukil penafsiran itu.

Terlepas dari itu semua, KH. Bishri dalam menafsirkan ayat-ayat al-Quran terkadang menggunakan terjemah bebas dan kadang juga sangat leterlek sesuai apa yang tertera dalam teks ayat.

Ke-leterlek-an Kiai Bishri dalam menerjemahkan ayat bisa dijumpai kebanyakan dalam hal ubudiyah atau ayat yang memang tidak membutuhkan penafsiran atau pentakwilan, seperti ayat 23 surah al-Isra'-10 وقضي ربك الا تعبدو الا اياه و بالو الدين احسانا, إما يبلغن عندك الكبر احدهما ام كلاهما

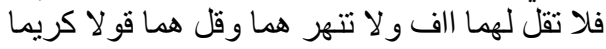

Ayat ini diartikan dengan apa adanya seperti bunyi teks yaitu Allah ta'āla wus perintah siro kabeh ora nyembah kejobo naming marang Panjenengan dewe, lan supoyo ambeciki marang wong tuwo loro, lamun salah suwijine wong tuwo loro utowo salah karo pisan wus tuwo, tur dadi tanggungan iro, ojo pisan-pisan siro ngucap marang deweke: "opo utowo "hush" lan siro nyentak marang wong tuwo loro, ngucapo marang wong tuwo loro sarono pangucap kang bagus. Dengan lain kata ayat tersebut diartikan Bishri (Allah telah memerintahkan, supaya kamu tidak

\footnotetext{
${ }^{9}$ Mushtofa Bisri, Al-Ibrīz li Ma'rifati Tafsir Qur'ān al-Azīz, Juz 1-10, (Kudus, Menara Kudus, t.t), 5

${ }^{10}$ Mushtofa Bisri, Al-Ibriz, 67
} 
menyembah selain-Nya dan supaya berbuat baik kepada kedua orang tua. Jika salah satu dari atau keduanya sudah lanjut usia dan menjadi tanggunganmu, maka jangan sekali-kali kamu berkata apa atau hush kamu jangan membentak keduanya. Berkatalah pada keduanya dengan perkataan yang baik dan halus).

Adapun disisi lain, tentang terjemahan bebas dia adalah ketika menafsirkan ayat-ayat yang mushtarak atau atau ayat-ayat yang ولا تجعل يدك مغلولة الي 29 mutasyabihat seperti mengartikan surat al-Isrā' ayat عنك و لا تبسطها كل البسط فتقعد ملوما محسور ا

Diartikan dengan tangan iro ojo siro belenggu ditafsirkan dengan ateges medit ora infaq babar pisan, lan iyo ojo iro beber babar pisan mundak-mundak siro dadi wong pinahidu yaitu meryo ora aweh babar pisan utowo dadi getun ora duwe opo (dijelaskan lagi mergo olehe infaq dikabehaken)

Penafsiran lain yaitu tentang mengartikan makna mutashābihāt seperti و وجه diartikan bukan wajah melainkan "Dzat Tuhan" dan juga ayat 67 surat al-Zumar, kata-kata بيمينه gata diartikan tangan kanan dan kemudian ditafsirkan dengan kekuasaan Allah.

Terlepas dari itu semua, bahwa tafsir al-Ibrïz mempunyai tempat di kalangan masyarakat khususnya orang jawa terbukti tafsir ini masih dipakai sampai sekarang.

\section{Al-Qur'an dan Tafsirnya karya Departemen Agama}

Salah satu karya tafsir yang dihasilkan oleh instansi pemerintahan adalah al-Quran dan tafsirnya karya Departemen Agama yang merupakan salah satu proyek pemerintahan dalam pembangunan lima tahun dimulai sejak pertengahan pelita pertama yang ide pertamanya adalah memenuhi kebutuhan masyarakat di bidang kitab suci dengan harapan agar dapat membantu umat Islam untuk lebih memahami kandungan ayat-ayat alQuran secara mendalam.

Adapun cara kerja mereka menyusun tafsir ini adalah dengan membagi menjadi dua tim yaitu tim Jakarta dan tim Yogyakarta yang di bagi dengan cara silang, semisal juz I Jakarta maka juz II Yogyakarta dan seterusnya kemudian pengoreksianya ditukar antara Jakarta dan Yogyakarta.

Tafsir Depag ini termasuk tafsir yang sangat komprehensif karena didalamnya dijelaskan dengan panjang lebar tentang penafsiran ayat tidak hanya terbatas pada kosa kata tetapi juga hal-hal yang berkaitan dengan ulum al-Quran semisal munāsabah ayat, asbab nuzul juga disertakan bahkan secara lengkap tentang ulum al-Quran dijelaskan dalam muqaddimah sebanyak 12 bab sehingga sangat wajar kalau tafsirnya-pun sangat besar yaitu 10 jilid. 
Adapun sistematika yang dipakai dalam penyusunan tafsir ini adalah menjelaskan ayat sesuai dengan runtutan ayat. Setiap awal surat selalu dimulai dengan menjelaskan identitas surat dan juga memberikan ringkasan informasi serta wawasan tentang ayat yang bersangkutan yang dikelompokkan menjadi dua bagian, pertama terdiri dari muqaddimah yang didalamnya dijelaskan panjang lebar asal usul surat, dan yang kedua tentang pokok-pokok isi dari ayat yang dibahas yang didalamnya terdapat keterangan panjang lebar tentang penafsiran ayat serta pencantuman asbāb al-nuzül kalau memang ada, kemudian di bagian akhir-pun selalu diberikan catatan singkat atau intisari serta hubungan surat yang sebelumnya dengan surat sesudahnya. Sehingga kecenderungan yang tampak di sini adalah penggunaan metode secara tahlili.

Salah satu keistemewaan dari tafsir Depag ini adalah adanya usaha mempermudah pemahaman orang ketika melihat tafsir ini, terbukti setiap menjelaskan surat selalu memberikan judul yang sesuai dengan kandungan apa yang dibahas dan tidak membiarkan lepas, dan juga adanya penjelasan kosa kata.

Tafsir bi al-ma'thür-pun sangat terlihat di sini terbukti dengan pengambilan sumbernya, karena sumber yang dipakai dalam tafsir ini adalah dengan mencantumkan ayat-ayat dan hadis Nabi yang terkait dengan pengertian ayat, perkataan sahabat dan juga tabi'in tidak terlepas pula karya ulama klasik seperti tafsìr al-Marāghì, Mahāsin al-Ta'wìl, Anwär al-Tanzīl wa Asrär al-Tafșìl, tafsìr ibnu Kathìr, tafsìr fì Zilāl al-Qur'ān, tafsìr alManār dan masih banyak lagi diambil dari berbagai disiplin ilmu, sehingga keluasan pembahasan-pun didapatkan, sangat wajar kalau kecenderungan dalam tafsir ini tidak tampak karena penulis hanya berusaha memaparkan semua aspek, tidak ke fiqih, falsafí, lughawi ataupun yang lain dan hanya berusaha memaparkan kalau memang pembahasan itu butuh dijelaskan secara luas maka akan dijelaskan agak lebar seperti ketika menafsirkan ayat 228 surat al-Baqarah bukan berarti dari situ bisa diambil kesimpulan mengenai coraknya, tetapi satu catatan penting tafsir ini sangat cenderung ke pemikiran golongan sunni. Hal itu terlepas dari back ground penulis atau mungkin karena kebanyakan orang Indonesia adalah sunni. Wallăhu a'lam. ${ }^{11}$

Upaya perbaikan-pun selalu diutamakan dalam tafsir ini, perbaikan yang pernah dihasilkan adalah perubahan dan perbaikan dalam tujuan dan saran, hadis yang dicantumkan lebih dipertegas dan juga di-takhrij dengan lengkap, format, isi kandungan, dan rujukanya, karena menurut tim tafsir Depag yang lama banyak sekali bahasa yang sulit difahami dan juga hadis yang dipakai belum takhrijj. Hal itu didasarkan dari adanya tujuan awal yaitu membuat karya yang bisa dijadikan rujukan oleh semua kalangan dan

\footnotetext{
${ }^{11}$ Harun Nasution, Falsafah dan Mistisisme dalam Islam, (Jakarta: Bulan Bintang, 1999), 12
} 
juga bebas dari domplengan suku, aliran dan ras, terbukti banyak sekali kalangan ketika menerjemahkan al-Quran merujuk kepada tafsir Depag. ${ }^{12}$ Tetapi kemudian satu pertanyaan penting adalah apakah memang tafsir ini bisa diambil dengan tanpa filter? Satu masukan penting dan juga bisa dikatakan sebagai kekurangan tafsir Depag ini adalah kurangnya ketelitian dalam menafsirkan, karena menurut penelitian ada satu kekeliruan ketika

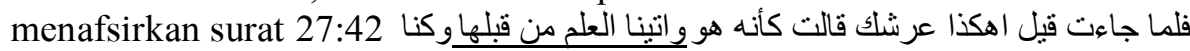
ayat yang digaris bawah diartikan bahwa yang berkata adalah Bilqis, padahal menurut penafsiran yang benar adalah Sulaiman.

\section{Tafsīr al-Bayān Karya Hasbi Ash-Sidieqy.}

Satu karya dari seorang yang sangat produktif dan hanya mendedikasikan dirinya untuk khazanah keislaman Indonesia walaupun pada satu kesempatan pernah terlibat dalam politik dan pejabat pemerintahan tetapi itu tidak mengurangi minat dia untuk berpaling adalah Prof. Dr. Teungku Muhammad Hasbi ash-Shidiqy yang diberi julukan ashShidiqy dengan karyanya Tafsir al-Bayān. Hashbi lahir di Lhokseumawe 10 Maret 1904 pendidikan dia dan kecenderungan serta minat dia berjalan searah sehingga wajar sudah banyak karya yang telah diterbitkan khusunya yang berhubungan dengan keislaman terutama tafsir dan hadis.

Munculnya karya ini adalah berangkat dari kegelisahan Hashbi terhadap penerjemahan yang berkembang saat itu dan juga upaya dia untuk memudahkan pemahaman atas karyanya sebelumnya yaitu al-Nür atau dengan kata lain sedikit banyak karya ini adalah merupakan penyempurna dari karyanya sendiri yang dinilai dia belum layak dan jauh dari sempurna yaitu tafsir al-Nür. Selain itu juga untuk membumikan ayat-ayat al-Quran di kalangan bangsa Indonesia yang banyak tidak faham dan menguasai bahasa Arab. ${ }^{13}$

Dalam menyusun al-Bayān ini, Hashbi berusaha melakukan penafsiran yang lebih ringkas dan mudah difahami yang tidak menimbulkan kerancuan apalagi perselisihan pendapat juga menempuh secara tahlili sesuai urutan ayat secara lengkap dari al-Fātihah sampai al-Nās, oleh karena itu dia memakai beberapa konsep penerjemahan diantaranya menerjemahkan makna lafadz dan menerjemahkan kalimat-kalimat dengan cukup yang hal itu dia jelaskan dalam footnote, mengertikan kalimat yang mengandung makna mushtarak dan ke-mushtarak-an itu dijelaskan semuanya, menerjemahkan lafadz-lafadz yang memerlukan penjelasan lebih lanjut, menyertakan makna karena disebabkan dari perbedaan I'rāb (aspek qirāāt) yang masing-masingnya-pun dijelaskan, menerangkan pendapat-

${ }^{12}$ Rasyidi, Dakwah Sufistik Rahmat: Menetramkan Jiwa mencerahkan Fikiran, (Jakarta: Paramadina, 2004), 35

${ }^{13}$ Islah Gusmian, Khazanah Tafsir Indonesia, (Jakarta: Teraju, 2003), 30 
pendapat para ulama dalam memaknai suatu ayat yang dipandang perlu dan dianggap penting dan menerjemahkan lafadz yang mutashābihāt seperti tentang sifat-sifat Allah.

Meskipun tafsir ini memiliki unsure tahlifi tetapi juga cenderung ijmāti, terlihat dari penafsiran dia yang secara global dan juga jelas, oleh karena itu penamaan al-Bayān pun tidak terlepas dari keinginan dia yang ingin menjadikan al-Quran sebagai penjelas bagi makna-makna al-Quran sekaligus penerang bagi kerancuan pemahaman masyrakat, yang dia nilai hal itu terdapat dalam al-Nür terperinci tapi tidak memberikan penjelasan yang kongkrit.

Sebagaiman dalam tafsir al-Nür, dalam al-Bayān pun Hashbi memberikan keterangan yang berhubungan dengan munāsabāt baik antarayat maupun antar-surat dalam penafsiranya, seperti dalam surat al-Baqarah ayat 14 di mengacu pada keterkaitan ayat 112 surat al-An'àm dalam memaknakan kata شيطان 14

Adapun yang sedikit banyak mengilhami dalam penulisan serta pemikirannya atas karya ini adalah tafsir al-Marāghi, Imam Izzudin ibn Jamā'ah dan juga sang modernis Muhammad Abduh.

Dari sekian catatan, satu hal yang menarik dari karya Hasbi asdShiddiqy ini adalah dia menyertakan pada pembukaan dengan mengawalinya tentang sejarah ringkas hidup Nabi Muhammad hingga turunya al-Quran dan juga disertakan kaidah-kaidah penafsiran al-Quran yang berhubungan tidak hanya dalam masalah ulum al-Quran tetapi juga kaidah kebahasaan dan ushul fiqih.

\section{Tafsir al-Huda Karya Bakri Syahid}

Satu lagi karya orang Jawa yang berbentuk tafsir adalah tafsir $A l-$ Hudā karya Bakri Syahid, Seorang Bakri Syahid yang terkenal sebagai Panglima Jendral ternyata tidak menghalangi untuk membuat karya yang sangat sarat akan nuansa-nuansa keislaman bahkan Qurani, hal itu juga dimungkinkan dari latar belakang dia yang pernah nyantri di sebuah Pesantren dan juga pernah berkiprah tidak hanya dalam lingkungan militer tetapi juga akademis, Bakri Syahid lahir di sebuah daerah yang sangat kental dengan tradisi ke-Jawa-anya bahkan disinyalir bahwa dia adalah keturunan keraton sehingga nuansa tafsirnyapun nuansa bahasa-bahasa kraton yang sangat halus dan tinggi yaitu Suraontan Ngampulan Jogjakarta 16 Desember 1918.

Penulisan tafsir ini bermula dari kegelisahan Bakri akan tingkah laku, tutur kata manusia terutama bangsa Indonesia dan terlebih lagi masyarakat Yogya dimana dia tinggal yang disinyalir Bakri sudah tidak lagi sejalan dengan apa yang ada dalam tuntunan al-Quran, oleh karena itu dia

\footnotetext{
${ }^{14}$ Hasbi as-Sidiqy, Tafsir al-Bayan, (Bandung: PT al-Ma'arif, 1966), 25
} 
merasa terpanggil untuk membuat semacam tafsir yang bisa dinikmati oleh masyarakat yang tidak mengerti al-Quran. ${ }^{15}$ Selain itu, tafsir ini juga menurut Bakri adalah merupakan bentuk silaturrahmi kepada para sahabatsahabat seperjuangnya baik di transmigrasi maupun teman-teman yang ada di Makkah dan Madinah yang asal-usulnya Jawa yang dan juga dorongan dari Mejelis Ulama Yogyakarta untuk membuat tafsir yang berbahasa Jawa karena disinyalir masih sangat sedikit tafsir yang memakai bahasa Jawa. ${ }^{16}$

Tafsir ini menurut Bakri ditulis sejak pertama kali tugas sebagai karyawan ABRI di sekertaris Negara pada tahun 1977 (masa orde baru) tetapi baru diterbitkan tahun 1979 oleh percetakan offset persatuan Yogya.

Sistematika yang diterapkan Bakri dalam menyusun tafsirnya ini adalah dengan menerjemahkan seluruh ayat-ayat al-Quran sesuai dengan susunan dalam mushaf dalam bahasa Jawa, satu keistimewaan dalam tafsir ini adalah Bakri menyertakan ayat al-Quran dengan tulisan latin di bawah tulisan Arab ayat karena dia menganggap bahwa masih sedikit orang-orang Jawa khusunya Yogya yang mayoritas pemeluk Islam abangan yang bisa membaca bahasa Arab. Memberikan footnote sebagai keterangan, memberikan penjelasan asbāb al-nuzūl ayat dan juga munāsabah-nya. Tidak lupa dibagian akhir memberikan catatan mengenai isi kandungan surat jika memang dia anggap dibutuhkan dengan banyak bersumber dari pemikiran dia sendiri yang fundamental. Oleh karena itu bisa dikatakan bahwa metode yang dipakai Bakri adalan tahlili dengan mengikuti runtutan ayat dan berbentuk Ra'yi sehingga wajar kalau penafsiranya sangat memihak dan bias sesuai dengan latar belakang penulis, meskipun demikian pada hal tertentu Bakri juga mendasarkan pendapatnya pada hadis tetapi tidak dijelaskan status hadisnya bahkan teks-nyapun tidak disertakan seperti penafsiran dia pada ayat ke-7 surat al-Fātihah dia sertakan sesudah baca alFātihah seharusnya baca āmīn, dan ini adalah merupakan keterangan yang ada di hadis Selain itu, dalam menafsirkan ayat terkadang juga dia mengacu pada ayat yang lain, seperti ketika menafsirkan ayat 11 surat al-Baqarah dia juga memperkuat pendapatnya dengan merujuk pada yat 213 al-Baqarah. ${ }^{17}$

Keluasan pengetahuan Bakri menjadi kelebihan tersendiri dalam tafsir ini, karena didalamnya semua aspek dijelaskan dan dinterpretasikan kecuali dalam makna yang mutashābihāt dia lebih cenderung tekstual seperti manafsirkan "yad" diartikan tangan, sehingga sangat sulit diidentifikasi kecenderungan Bakri dalam tafsirnya. Walaupun demikian dalam beberapa tempat corak fikihlah yang lebih dominan, hampir pada

\footnotetext{
${ }^{15}$ Imam Muhsin, al-Quran dan Budaya Jawa, (Yogyakarta: Elsaq Press, 2013), 10

${ }^{16}$ Imam Muhsin, Tafsir al-Quran dan Budaya Lokal: Studi Nilai-nilai Budaya Jawa dalam Tafsir al-Huda Karya Bakri Syahid, (tk: Badan Litbang dan Diklat Kementrian Agama RI, 2010), 22-25

${ }^{17}$ Bakri Syahid, Kitab Tafsir al-Huda, (Yogyakarta: Bagus Arafah, 1979), 4-10
} 
ayat-ayat yang berkenaan dengan fiqih Bakri selalu memberikan komentar, contoh ketika menafsirkan ayat tentang riba يا ايها الذين امنوا لا ناكلوا الربا اضعافاف Bakri didalamnya panjang lebar menjelaskan tentang riba baik macamnya maupun respon masyarakat Muslim tentang riba. Tetapi selain fiqih adab al-ijtimāi $i$-pun cenderung sering ditampilkan dalam penafsiranya seperti penafsiranya pada ayat فلاتجطواله اندادا yang artinya musyrik ditafsirkan Bakri dengan menyembah selain Allah baik mengagungkan pohon dan sejenisnya, benda yang dikeramatkan, gua, berhala atau hal-hal yang berbau mistik yang pada saat itu tradisi semacam pengkeramatan atas benda-benda mati yng dianggap sakti oleh masyarakat sangat kental semisal kultus pemujaan pusara para raja-raja. Dari dua contoh itu bisa mewakili untuk mengatakan bahwa corak yang ada dalam tafsir al-Huda ini adalah adab al-ijtimái dan juga Fiqih, karena yang tampak dari keseluruha tafsirnya adalah dua dominasi itu dengan tidak mengenyampikan dominasi yang lain tetapi hanya sedikit keteranganya dan tidak mendominasi. ${ }^{18}$

Adapun keistimewaan tafsir ini selain yang sudah disebutkan di atas yaitu sebagai tafsir pertama yang menampilkan tulisan latin dalam ayat-ayatnya, yaitu disertakanya dalam bagian akhir menganai hal-hal yang berkenaan dengan rukun rukun Islam, tata cara shalat dengan sangat detail, yaitu dari proses awal (niat) sampai salam yang didalmnya juga disertakan gambar, sehingga terkesan bahwa sasaran tafsir ini adalah orang yang sangat awam yang belum mengerti Islam atau bahkan bisa dibilang muallaf. Terlepas dari itu tafsir al-Huda ini diperuntukkan untuk semua kalangan tidak hanya akademis dan kraton yang mampu mengaksesya tetapi juga masyarakat awam. ${ }^{19}$

\section{Tafsir Rahmat Karya Oemar Bakri}

Di antara tafsir yang lahir pada abad 20 adalah Tafsir Rahmat Karya Oemar Bakri. Oemar Bakri sendiri yang nama lengkapnya adalah Oemar Bakri Dt Tan Besar dilahirkan pada tanggal 26 Jui 1916 di Desa kacang di pinggir danau singkarak Sumatera Barat yang banyak menghasilkan tidak hanya dalam bidang tafsir tetapi juga bidang keislaman yang lain yang kira-kira sekitar 21 karya, hal itu mungkin dipicu dari pendidikan beliau yang tinggi dan beragam. ${ }^{20}$

Bakri merasa tergerak untuk menulis tafsir di samping karena keilmuwan yang dia miliki adalah karena juga keinginan dia untuk

\footnotetext{
${ }^{18}$ Fauziah dian Umami, Penafsiran Sosial Politik dalam Tafsir al-Huda Basa Jawi Karya Bakri Syahid, (tt.tp), 21

${ }^{19}$ Fauziah dian Umami, Penafsiran.., 29

${ }^{20}$ Howard Federsfiel, Kajian al-Quran di Indonesia dari Mahmud Yunus Hingga Quraish Syihab, (Bandung: Mizan, 1979), 56
} 
membantu pembaca untuk memahami al-Quran dan juga sebagai jawaban atas permintaan dari pembaca al-Quran agar memberikan karya-karya yang lebih baik untuk penggunaan dan pengkajian al-Quran. Dalam penulisan tafsir ini dia termasuk relatif cepat karena telah mampu menyelesaikan dalam waktu kurang lebih tiga tahun (1981-1983). ${ }^{21}$

Metode yang digunakan Bakri dalam penulisanya adalah Tahlili yaitu sesuai runtutan al-Quran, tetapi dalam penulisan tafsirnya ini dia hanya mengugkapkan makna-makna global, tidak menjelaskan arti kata terlebih dahulu, padahal disinyalir para ahli bahasa hal itu adalah penting, karena terkadang walaupun lafadznya sama tetapi makna-nya berbeda مetika dikaitkan dengan konteks yang tidak sama, seperti kasus ayat مالك الدين mengandung arti Yang mempunyai hari pembalasan arti اليوم الدين disini diartikan pembalasan, padahal lafadz الدين dalam konteks yang lain artinya adalah Agama yaitu ان الدين عند الله الإسلام . Selain global, Bakri juga menafsirkan secara sederhana, ringkas dan tidak mengaitkan dengan masalah-masalah lain, tetapi walaupun demikian, Bakri juga memakai hadis sebagai penunjang penafsiranya. ${ }^{22}$

Corak pemikiran yang sangat menonjol dalam penafsiran Bakri adalah tradisional yaitu penafsiran harfiyah khususnya yang menarik perhatian adakah ketika menafsirkan ayat-ayat mutashābihāt, karena didalamnya merupakan lapangan bagi mufassir untuk "berkreasi" dalam menafsirkan ayat karena memang tidak ada pemaknaan yang pasti, tetapi Bakri lebih berhati-hati dengan memilih menafsirkan secara harfiyah. Dalam hal sumber, Bakri tidak hanya menfokuskan pada karya tentang alQur'an, tapi juga ulūm al-Qur'an, Balāghah, bahasa Inggris dan juga ensiklopedia.

Sekilas tampak bahwa penafsiran Bakri itu hanya merupakan karya yang biasa-biasa saja, tetapi setelah ditilik dan ditelaah banyak keistimewaan yang dikandungnya, diantaranya pengalihan Bakri dari perhatian yang hanya menfokuskan pada bahasa Arab ke pambaharuan kata, istilah-istilah dan teknik dalam peningkatan pemahaman dalam terjemah bahasa Indonesia terutama mengacu pada bahasa Indonesia yang telah disempurnakan dan modern serta memperhatikan perkembangan zaman dari pada tafsir-tafsir yang lebih tua seperti ketika menafsirkan kata السموات yang bisanya diartikan langit kemudian diartikan dengan ruang angkasa. Selai itu, Bakri juga berupaya memberikan penjelasan selengkap-lengkapnya dengan memberikan penjelasan tambahan kepada penerjemahan al-Quran terutama jika yang diberikan hanya penerjemahan teks yang akan menimbulkan pertanyaan pembaca yang ditulis di dalam kurung, seperti menerjemahkan kata \& yang biasanya diartikan "mereka" secara umum,

\footnotetext{
${ }^{21}$ Oemar Bakri, Tafsir Rahmat, (Jakarta: Mutiara, tt), 2

${ }^{22}$ Oemar Bakri, Tafsir... 23
} 
kemudian Bakri memberikan tambahan dalam kurung sesuai dengan yang dimaksudkan seperti dia laki-laki, dia benda dan yang lain. Semua itu untuk mempermudah membaca dan memahami al-Quran bagi masyarakat Indonesia. ${ }^{23}$

Keistimewaan yang lain adalah penekanan Bakri pada pembahasan al-Quran yang sesuai dengan perkembangan teknologi dengan menyertakan indeks yang terkandung didalamnya tema-tema yang dilengkapi dengan rujukan teks-teks yang sesuai seperti aqidah, akhlak, hokum, dan yang lain, Bakri di dalam tafsirnya juga menampilkan munāsabah antar-surah sebelum dia menafsirkan. Dari penekanan yang disertakan dalam tafsirnya, penafsiran Bakri cenderung ilmiyah karena banyaknya penekanan yang dia jelaskan adalah tentang yang berhubungan dengan teknologi misalnya, tetapi corak yang lain-pun tidak kalah jelasnya. Sehingga tidak mengurangi dari nilai tafsir ini.

\section{Tafsir al-Misbah Pesan, Kesan Dan Keserasian al-Qur'an Karya Quraish Shihab}

Muhammad Quraish Shihab, lahir 16 Februari 1944 M, di Rappang, Sulawesi Selatan adalah seorang ahli tafsir Asia Tenggara. Beliau telah banyak menulis berbagai macam buku, dan salah satu karya monumentalnya adalah tafsir al-Misbah.

Pendidikan dasarnya diselesaikan di Ujungpandang, kemudian melanjutkan pendidikan menengahnya di Malang sambil "nyantri" di pondok pesantren Dar al-Hadits al-Fiqihiyyah. Ia berasal dari keluarga keturunan Arab yang terpelajar. Ayahnya bernama Abdurrahman Shihab (1905-1986) adalah lulusan Jami'ah al-Khair Jakarta, sebuah lembaga pendidikan Islam tertua di Indonesia yang mengedepankan gagasan-gagasan Islam modern.

Dari ayahnya dia banyak memperoleh inspirasi sehingga perjalanan pendidikannya juga memgambil jurusan tafsir, sama seperti ayahnya yang menjadi guru besar tafsir dan rektor IAIN Alaudin Makasar. Ia mengejar cita-cita sampai ke Kairo. Ia menyelesaikan S2 dan S3-nya di sana. Judul disertasinya "Nazm al-Durār li al-Biqā'i tahqīq wa Dirāsah", meraih penghargaan tingkat I (Mumtāz ma'a martabat al-sharaf al-awlā). Ia menjadi orang pertama di Asia Tenggara yang meraih gelar doktor dalam ilmu-ilmu al-Qur'an di Universitas Al-Azhar. ${ }^{24}$

Kenikmatan ruhani yang terasa ketika bersama al-Qur'an, sehingga mengantarkan Quraish Shihab untuk mengkaji, membaca dan menulis tafsir al-Misbah. Bentuk penulisan yang digunakan adalah ma'thür. Dimana

\footnotetext{
${ }^{23}$ Tajul Arifin, Kajian al-Quran di Indonesia Terj. Populer Indonesia Literature of The Quran. Howard M. Federsfiel. (Bandung: Mizan, 1996), 35

${ }^{24}$ Wikipedia, Wkipedia The Free Encyclopedia
} 
beliau menggunakan ayat yang lain untuk menfasrikan al-Qur'an dan memaknai setiap kata dengan teliti, cermat dan dari berbagai sudut pandang. Dimana di setiap awal surah, diurai dengan detail masalah yang berkaitan dengan surah yang dikaji. Misalnya tentang jumlah ayat, tematema yang menjadi pokok kajian dalam surah, nama-nama lain dari surah tersebut, munāsabah antar-surah atau ayat, penejelasan asbāb al-Nuzūl, penjelasan ayat dengan menguraikan makna mufradăt, dan lain sebagainya.

Quraish Shihab menggunakan metode analisis (tahlili) yang dicampur juga dengan metode maudư $\bar{i}$. Beliau menjelaskan terlebih dahulu tentang: tempat turunnya surah, nama lain surah tersebut, munāsabah surah dengan surah sebelumnya, tujuan utama surah tersebut, kemudian ia mulai menafsirkan ayat baik ditinjau dari segi asbāb al-Nuzūl-nya, analsis kandungan ayat serta makna mufradah dan yang lainnya. Seperti tafsir surah al-Mā'ūn: "Araaitalladhī yukadhdhibu bi al-dīn (1) Fazālikalladhī yadu'u al-yatīm (2) Walā yahuddu 'alā ta'āmi al-miskīn (3)." ${ }^{25}$

Kata menurut analsisnya berarti makanan atau pangan. Ayat tersebut tidak menggunakan redaksi اطعام memberi makan, tetapi طعام pangan agar setiap orang yang menganjurkan atau memberi itu, tidak merasa bahwa ia telah memberi makan orang-orang yang butuh. Ini mengisyaratkan bahwa pangan yang mereka anjurkan atau mereka berikan itu, pada hakikatnya walaupun diambil dari tempat penyimpanan yang "dimiliki" si pemberi, tetapi apa yang diberikannya itu bukan miliknya, tetapi hak orang-orang miskin dan butuh itu. ${ }^{26}$

Corak yang dipilih oleh Quraish Shihab dikategorikan pada corak Adabỉ Ijtimā'i yaitu suatu corak yang menitikberatkan penjelasan ayat alQur'an pada segi ketelitian redaksi al-Qur'an, kemudian menyusun kadungan ayat-ayat tersebut dalam suatu redaksi yang indah dengan menonjolkan tujuan diturunkannya al-Qur'an, yakni sebagai petunjuk dalam kehidupan, kemudian menggandengkan pengertian ayat-ayat tersebut dengan hukum-hukum alam yang berlaku dalam masyarakat dan pembangunan dunia. ${ }^{27}$

Kemampuannya mengekspolasi kata-kata dan memahami makna dari berbagai sudut pandang merupakan alat yang digunakan dalam menafsirkan al-Qur'an. Tidak salah jika, dalam tafsir al-Misbah ini, ketelitian redaksi al-Qur'an, kemudian menyusun kandungan ayat-ayat tersebut dalam suatu readaksi yang indah dengan menonjolkan dari tujuan dari tujuan diturunkannya al-Qur'an, yakni sebagai petunjuk dalam

\footnotetext{
${ }^{25}$ Hasan Yunus Abidu, Tafsir al-Quran, Sejarah dan Metode para Mufassir, (Jakarta: Gaya Media Pratama, 2007), 60

${ }^{26}$ Q. S. al-ma'un (107: 1-3). Lihat M. Quraish Shihab, Tafsir al-Misbah, 15:545.

27 M.Quraish Shihab, Metode Penyusunan Tafsir yang Berorientasi pada Sastra, Budaya dan Kemasyaraktan, Makalah (Ujungpandang: IAIN Alaudin, 1984),1.
} 
kehidupan, kemudian menggandengkan pengertian ayat-ayat tersebut dengan hukum-hukum alam yang berlaku dalam masyarakat dan pembangunan dunia. Di sinilah letak kelebihan beliau, yang mengusai makna bahasa Arab secara mendalam, sehingga dapat menghasilkan tafsiran yang dapat mendekati karakter dan maksud dari firman Allah, dengan kaidah bahasa Indonesia yang baik dan manarik.

\section{Epilog}

Sejarah penafsiran al-Qur'an di Indonesia sudah dimulai sejak abad ke-17 dan mulai menemukan momentumnya ketika Islam sudah tersebar di Indonesia, terbukti dengan adanya karya-karya anak bangsa. Di antara sekian banyak tafsir, penulis hanya mengulas dengan cara mendeskripsikan sebagian kitab tafsir, yaitu Marah Labid karya Nawawi al-Bantani dikarang dengan menggunakan bahasa Arab metode tradisional dan ma'thür dengan bercorak sufi dan lughawi. 2) Tafsir al-Qur'an al-Karim karya Mahmud Yunus, tafsir ini lebih condong pada sistem penerjemahan tetapi dengan memasukkan penafsiran di dalamnya, menggunakan metode tahlili dengan gaya pemikiran modernis. 3) tafsir al-Ibriz karya KH. Bishri Musthafa ditulis dengan bahasa Jawa yang kental dengan pemikiran pribadi penulis yang ditopang dalil al-Quran dan hadis, menggunakan metode tahlifi manhāj bil ma'thür. 4) al-Quran dan tafsirnya karya Departemen Agama disusun dengan tujuan memenuhi program 'pelita' dengan metode tahlili dan ijmā̄í. 5) Tafsìir al-Bayān karya Hasbi ash-Sidieqy sebagai penyempurna kitab sebelumnya yaitu al-Nur dengan menggunakan metode tahlïi dan cenderung ijmāti. 6) Tafsìir al-Hudā karya Bakri Syahid disusun dengan bahasa Jawa khas keraton yang bercorakkan adabī al-ijtimā'i dan juga fiqih dengan metode tahlili. 7) Tafsir Rahmat karya oemar bakri dengan menggunakan metode tahlili dan memakai corak ilmi, 8) Tafsir alMisbah Pesan, Kesan dan Keserasian al-Qur'an karya Quraish Syihab metode yang digunakan adalah analisis ( $\operatorname{tah} / \bar{i} / \overline{1})$ yang dicampur juga dengan metode mauḍu' $\bar{i}$ yang bercorak pada corak Adabī Ijtimā'í.

Dari tafsir-tafsir ini, penulis berharap akan ada pengembangan untuk mengulas dari kitab-kitab tersebut dengan lebih dalam dan mendetail. Selain itu juga, semoga akan ada pembahasan dari kitab di Indonesia yang belum dibahas di atas.

\section{Daftar Pustaka}

Abidu, Hasan Yunus. Tafsir al-Quran, Sejarah dan Metode para Mufassir. Jakarta: Gaya Media Pratama, 2007.

Amin, Samsul Munir. Sayyid Ulama Hijaz: Biografi Syaikh Nawawi alBantani. Jakarta: Bulan Bintang, t.t. 
Al-Qur'an Dalam Sejarah Penafsiran Indonesia

Arifin, Tajul. Kajian al-Quran di Indonesia Terj. Populer Indonesia Literature of The Quran. Howard M. Federsfiel. Bandung: Mizan, 1996.

Baidan, Nashrudin. Perkembangan Tafsir al-Quran di Indonesia. Tiga Serangkai, 2003.

Bakri, Oemar. Tafsir Rahmat. Jakarta: Mutiara, tt.

Bisri, Mushtofa. Al-Ibriz li Ma'rifati Tafsir Quranil Aziz, Juz 1-10. Kudus: Menara Kudus, t.t.

Al-Farmawi, Abd al-Hay. Bidayah Fiy al-Tafsir al-Maudhu'I. Kairo: Hadrat al-Ghorbiyah, 1977.

Federsfiel, Howard. Kajian al-Quran di Indonesia dari Mahmud Yunus Hingga Quraish Syihab. Bandung: Mizan, 1979.

Gusmian, Islah. Khazanah Tafsir di Indonesia. Jakarta: Teraju, 2002.

Muhammad, Herry dkk. Tokoh-tokoh Islam yang berpengaruh abad 20. Depok: Gema Insani, 2006.

Muhsin, Imam al-Quran dan Budaya Jawa. Yogyakarta: Elsaq Press, 2013.

---------, Tafsir al-Quran dan Budaya Lokal: Studi Nilai-nilai Budaya Jawa dalam Tafsir al-Huda Karya Bakri Syahid. tk: Badan Litbang dan Diklat Kementrian Agama RI, 2010.

Mursid M dan Amarudin Asra, Studi Tafsir Quran Karim karya Mahmud Yunus, Jurnal Syahadah, Vol 3, No.2, Oktober 2015.

Nasution, Harun. Falsafah dan Mistisisme dalam islam. Jakarta: Bulan Bintang, 1999.

Nawawi, Muhammad al-Jawi, Marah Labid Tafsir al-Nawawi, Vol.I. Surabaya: al-hidayah, t.t.

Rasyidi. Dakwah Sufistik Rahmat: Menetramkan Jiwa mencerahkan Fikiran. Jakarta: Paramadina, 2004.

Rokhmad, Abu. Telaah Karakteristik Tafsir Arab-Pegon al-Ibriz, Jurnal 'Analisa' Vol. XVIII, No. 01, Januari-Juni 2001.

asy-Sidiqy, Hasbi. Tafsir al-Bayan. Bandung: PT al-Ma'arif, 1966.

Shihab, M. Quraish. Tafsir al-Misbah, 15:545.

. Metode Penyusunan Tafsir yang Berorientasi pada Sastra, Budaya dan Kemasyaraktan, Makalah . Ujungpandang: IAIN Alaudin, 1984.

Syahid, Bakri Kitab Tafsir al-Huda. Yogyakarta: Bagus Arafah, 1979.

Umami, Fauziah dian. Penafsiran Sosial Politik dalam Tafsir al-Huda Basa Jawi Karya Bakri Syahid. tt.tp.

Wikipedia, Wkipedia The Free Encyclopedia

Yunus, Mahmud. Tafsir al-Quranil Karim. Jakarta: PT. Mahmud Yunus wa Dzurriyah, 2015. 